Infectious anastomotic pseudoaneurysm

\title{
complicating renal allograft: case report and review of literature
}

This article was published in the following Dove Press journal: International Journal of Nephrology and Renovascular Disease 20 February 2017

Number of times this article has been viewed

\author{
Marvin MT Chung \\ Yiu Che Chan \\ Yuk Law \\ Stephen WK Cheng
}

Division of Vascular and Endovascular Surgery, Department of Surgery, University of Hong Kong Medical Centre, Queen Mary Hospital, Hong Kong
Correspondence:Yiu Che Chan Division of Vascular and Endovascular Surgery, Department of Surgery, University of Hong Kong Medical Centre, South Wing, I4th Floor K Block, Queen Mary Hospital, Pokfulam Road, Hong Kong

Tel+852 22554969

Fax+852 22554967

Email ycchan88@ hkucc.hku.hk

\begin{abstract}
Infectious anastomotic pseudoaneurysm complicating renal transplant is rare, but probably under-reported with $<30$ cases worldwide. We report a 45 -year-old man with hypertension, diabetes mellitus and end stage renal failure, who had a renal transplant anastomosed to the right external iliac artery and vein. Postoperatively, he made a slow recovery with malaise and persistent vague right iliac fossa discomfort. Ultrasound scan 1 month postoperatively showed perinephric collection, and fluid culture grew Enterococcus faecium and Pseudomonas aeruginosa. He was started on vancomycin, daptomycin and colistin. MAG-3 scan also showed suboptimal function in the renal allograft. His symptoms persisted with fever, and blood culture yielded $P$. aeruginosa. Repeated ultrasound scan, and subsequent computed tomography scan a few weeks later, showed perinephric collection and a large, $3.8 \times 3.5 \mathrm{~cm}$ pseudoaneurysm posteromedial to the graft kidney. He underwent emergency graft excision, together with resection of the pseudoaneurysm with in situ reversed great saphenous vein interposition graft, and made a good recovery on hemodialysis. The aneurysm wall grew $P$. aeruginosa, and he was put on imipenem and cilastatin (tienam), colistin, ciprofloxacin and daptomycin. To our knowledge, this is one of very few cases in the world's literature in which a $P$. aeruginosa infectious anastomotic pseudoaneurysm developed after a renal allograft.
\end{abstract}

Keywords: infectious anastomotic pseudoaneurysm, renal allograft artery, renal transplant, multidrug-resistant Pseudomonas aeruginosa, in situ interposition bypass graft.

\section{Introduction}

Infectious anastomotic pseudoaneurysm after renal transplant is a rare, but serious complication. This condition might be under-reported, with $<30$ cases identified in contemporary literature worldwide. In this article, we describe a diabetic patient with end-stage renal failure who received a renal transplant which was complicated with a large infectious pseudoaneurysm of the renal artery allograft requiring emergency graft nephrectomy and excision of pseudoaneurysm with vascular reconstruction.

\section{Case report}

A 45-year-old man with hypertension and end-stage renal failure due to diabetic nephropathy on peritoneal dialysis received a cadaveric renal transplant in other region with unknown donor and matching information. The allograft vessels were anastomosed to the external iliac artery and vein respectively. He was put on tacrolimus $2.5 \mathrm{mg}$ twice daily, mycophenolate mofetil $750 \mathrm{mg}$ twice daily and prednisolone $10 \mathrm{mg}$ daily after transplant for immunosuppression. Postoperatively, he had a slow 
recovery with persistent malaise and right lower quadrant pain and fever 3 weeks after the renal transplantation. Serum creatinine level was $452 \mu \mathrm{mol} / \mathrm{L}$. Physical examination at that stage showed that the right lower quadrant was mildly tender over the transplanted kidney site with a well-healed scar. Ultrasound scan of the abdomen 1 month postoperatively revealed normal-looking graft kidney with anterior perinephric fluid collection, while the graft renal artery was obscured. Ultrasound-guided pigtail was inserted for drainage and yielded dark red turbid fluid, and the fluid culture grew Enterococcus faecium and Pseudomonas aeruginosa. Daptomycin, vancomycin and colistin were, therefore, commenced after discussion with the microbiologist. His renal function gradually deteriorated with serum creatinine rising up to $679 \mu \mathrm{mol} / \mathrm{L}$. Serial ultrasound scan showed reduction in collection and the pigtail drain was removed. An MAG-3 radioisotope scan of the graft kidney showed reduced perfusion and suboptimal renal allograft artery function.

Upon completion of the course of the above antibiotics, he developed fevers and chills, and blood culture yielded P. aeruginosa. Fluid aspiration of the perinephric collection was again performed, with the culture yielding the same multidrug-resistant Pseudomonas. A computed tomography (CT) scan of the abdomen and pelvis 3 months posttransplantation showed a $3.8 \times 3.5 \mathrm{~cm}$ hyperdense, irregular, lobulated contrast outpouching of the right external iliac artery at the posteromedial aspect of the graft kidney, which represented an anastomotic pseudoaneurysm of the graft renal artery (Figure 1).

In view of the uncontrolled sepsis despite maximal conservative treatment, the patient was transferred from the renal unit to our tertiary vascular referral center for surgical management. He underwent emergency graft nephrectomy with resection of the right external iliac artery pseudoaneurysm and vascular reconstruction with in situ reversed great saphenous vein interposition graft harvested from the left thigh (Figure 2). Copious lavage of extraperitoneal and intraperitoneal space was performed prior to closure of the wound. The aneurysm wall grew multidrug-resistant P. aeruginosa, and he was put on imipenem and cilastatin (tienam), colistin, ciprofloxacin and daptomycin. Postoperatively, he made a good recovery on hemodialysis with no further sepsis, as evidenced by downtrend of inflammatory markers and resolution of fever. Postoperative 1 month CT scan and 4 months duplex ultrasound scan showed patent vein graft and resolution of collection (Figure 1). He was then transferred to his regional renal unit for continuation of hemodialysis. The vein graft was still patent without evidence of infection at 6 months postoperation at our outpatient follow-up.

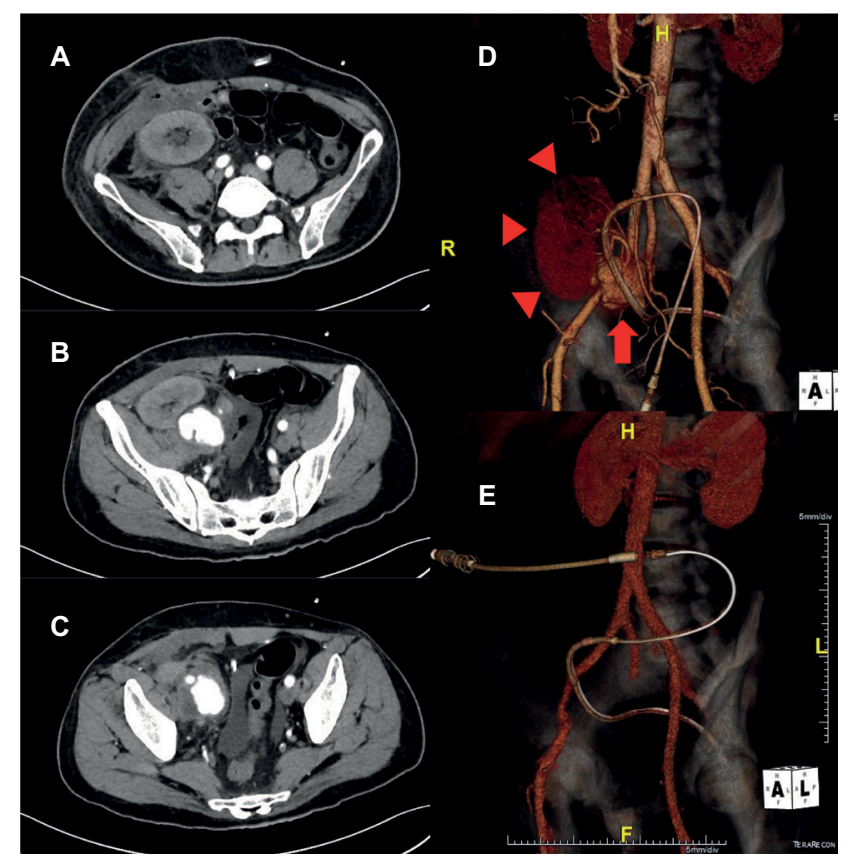

Figure I CT scan of the abdomen and pelvis 3 months post-renal transplant shows (A) perinephric collection with gas density, and (B and C) a $3.8 \times 3.5 \mathrm{~cm}$ infectious pseudoaneurysm of the graft renal artery. (D) 3-Dimensional reconstruction of the CT scan showing the pseudoaneurysm arising from the anastomosis between allograft renal artery and EIA (red arrow). The graft kidney is outlined by red triangles. (E) Postoperative 3-dimensional reconstruction of the CT scan showing patent vein graft and EIA. Graft kidney and pseudoaneurysm were removed.

Abbreviations: $\mathrm{CT}$, computed tomography; EIA, external iliac artery; R, right; L, left; $\mathrm{H}$, head; $F$, foot.

The patient gave informed written consent for publication of this report.

\section{Discussion}

Vascular complications after renal transplantation, such as renal artery stenosis, arterial thrombosis, venous thrombosis, arteriovenous fistula and renal artery pseudoaneurysm, are probably under-reported, with an occurrence rate ranging from $3 \%$ to $15 \% .{ }^{1}$ Pseudoaneurysms of the renal allograft artery are particularly dangerous as they show risks of rupture which are potentially lethal. While anastomotic pseudoaneurysms have been reported since $1985,{ }^{2}$ infectious pseudoaneurysms have been rarely reported and were often associated with graft loss in the case reports and series available in literature (Table 1). ${ }^{3,4}$ They usually present with a wide spectrum of presentation, ranging from iliac fossa pain and fever to lower limb ischemia or even hemorrhagic shock due to rupture of pseudoaneurysm. Causes of infectious aneurysm formation are multifactorial. Post-renal transplant patients often have multiple risk factors for opportunistic infections: intake of immunosuppressants, end-stage renal failure and diabetes mellitus in patients with diabetic nephropathy. Infectious pseudoaneurysms secondary to septicemia ${ }^{5}$ or 


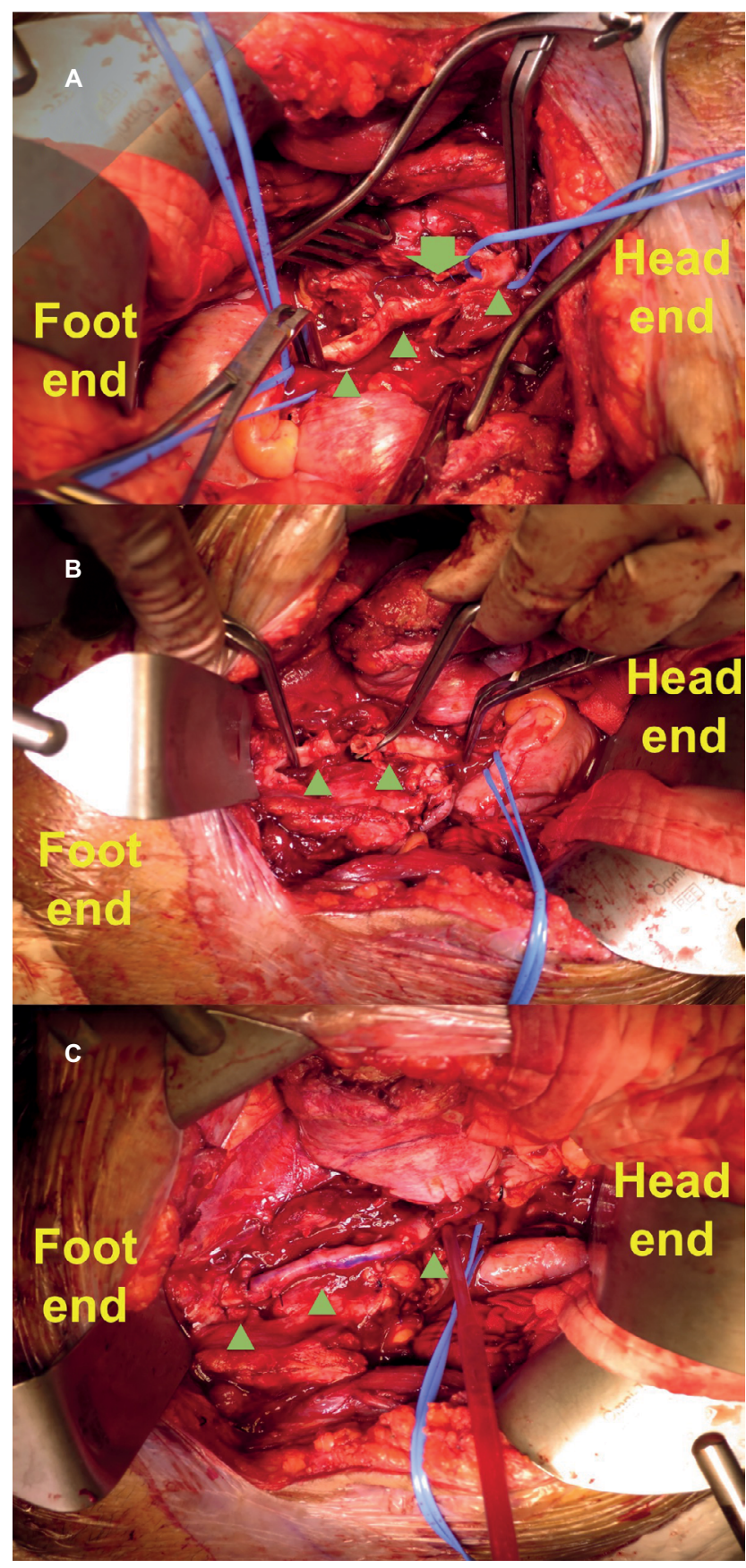

Figure 2 (A) Intraoperative photos after graft nephrectomy and excision of pseudoaneurysm. Green arrow points to the large defect over EIA (marked by green triangles). (B) The distance between two ends of the EIA was too sizable to allow primary anastomosis. (C) Vascular reconstruction was achieved with reversed great saphenous vein interposition graft (marked by green triangles).

Abbreviation: EIA, external iliac artery.

contaminated preservation solution in the process of graft handling have been reported. ${ }^{6}$ Evidence of chronic rejection in histopathologic examination was also shown in up to $60 \%$ of infectious pseudoaneurysms in a case series. ${ }^{3}$ Reliable donor graft, antibiotic prophylaxis (our unit uses single intravenous dose of ceftriaxone on induction), strict infection control during transplant operation and aseptic handling of the graft or preservation fluid are some of the measures to prevent this devastating condition.

As the condition is rare, most cases reported in the literature were either case reports or case series. Table 1 summarizes contemporary literature on all reported cases of infectious anastomotic pseudoaneurysms of renal allograft artery. Among the 30 reported cases of infectious pseudoaneurysms, $76.7 \%$ yielded fungus growth in the resected specimen, although there are also severe cases with growth of bacteria such as Pseudomonas, Klebsiella and Staphylococcus. The high occurrence of fungal infection could be explained by the immunocompromised status of posttransplant patients and also the angioinvasive nature of fungi. ${ }^{7,8}$ Leonardou et al reported two cases with P. aeruginosa isolated from the blood culture, and both patients were treated with ciprofloxacin for 4 weeks in total after surgery. ${ }^{4}$ No recurrence was detected up to 36 months. Unfortunately, in our patient, no single antibiotic agent was able to control the infection. The Pseudomonas species isolated from the patient's blood culture and aneurysm sac was resistant to tazocin, meropenem, timentin, cefepime and gentamicin. As of this date, this is the first reported case of infectious anastomotic pseudoaneurysm caused by multidrug-resistant $P$. aeruginosa, which required multiple lines of antibiotics on top of surgical treatment.

Most authors in recent literature advocated a multidisciplinary management approach ${ }^{4}$ comprising both medical treatment with antibiotics and surgical management. Although the gold-standard surgical treatment of infectious anastomotic pseudoaneurysms of renal allograft artery involves graft nephrectomy and resection of pseudoaneurysm with vascular reconstruction, ${ }^{4,9}$ endovascular means could be used in selected cases when the risk of extensive arterial wall defect is not high. ${ }^{10}$ Smeds et al made a successful attempt in excluding a noninfectious anastomotic pseudoaneurysm using a kissing covered stent, with successful preservation of the arterial blood flow to the graft kidney and good stent patency in 1-month surveillance CT angiography. ${ }^{11}$ Most series had shown the graft nephrectomy was inevitable, especially if the anastomosis had disintegrated as in our case. After radical debridement of the infectious aneurysm, interposition bypass grafts using venous or autogenous internal iliac artery graft were necessary to establish vascular continuity. ${ }^{8}$ Osmán et al attempted endovascular stenting prior to nephrectomy to avoid the ligature of iliac artery, but it was complicated with large abscess around the stent with large vascular defect, eventually necessitating ligation of the common and external iliac arteries and femoral-femoral bypass. ${ }^{10}$ Nevertheless, 
Table I List of case reports on infectious pseudoaneurysm of the renal allograft artery in the literature; nonmycotic pseudoaneurysms are excluded

\begin{tabular}{|c|c|c|c|c|c|c|}
\hline Study & Sex & $\begin{array}{l}\text { Age, } \\
\text { years }\end{array}$ & Treatment modality & Initial clinical presentation & $\begin{array}{l}\text { Symptom onset } \\
\text { posttransplant }\end{array}$ & Culture results \\
\hline Potti et al ${ }^{12}$ & M & 60 & $\begin{array}{l}\text { Repair of ruptured aneurysm, } \\
\text { then graft nephrectomy }\end{array}$ & N/A & 6 weeks & Candida albicans \\
\hline Garrido et $\mathrm{al}^{13}$ & $\mathrm{~F}$ & 53 & $\begin{array}{l}\text { Graft nephrectomy with excision } \\
\text { of pseudoaneurysm }\end{array}$ & Acute right lower limb ischemia & 5 weeks & Aspergillus \\
\hline Garrido et $\mathrm{al}^{13}$ & $\mathrm{~F}$ & 56 & $\begin{array}{l}\text { Graft nephrectomy with excision } \\
\text { of pseudoaneurysm }\end{array}$ & Acute right lower limb ischemia & 6 months & Aspergillus \\
\hline Laouad et al ${ }^{14}$ & M & 35 & $\begin{array}{l}\text { Graft nephrectomy with excision } \\
\text { of pseudoaneurysm }\end{array}$ & Fever, acute renal failure & 3 months & C. albicans \\
\hline Laouad et al ${ }^{14}$ & M & 24 & - & Cardiac arrest & 9 days & C. albicans \\
\hline Laouad et $\mathrm{al}^{14}$ & M & 55 & Graft nephrectomy & Fever, oliguria & 7 weeks & C. albicans \\
\hline Laouad et $\mathrm{al}^{14}$ & $F$ & 39 & Graft nephrectomy & Fever & 3 months & C. albicans \\
\hline Fujikata et $\mathrm{al}^{5}$ & M & 59 & Antibiotics alone & Fever & 2 weeks & $\begin{array}{l}\text { Methicillin-resistant } \\
\text { Staphylococcus aureus }\end{array}$ \\
\hline Osmán et al ${ }^{10}$ & M & 15 & $\begin{array}{l}\text { Covered stent insertion, then } \\
\text { graft nephrectomy with femoral- } \\
\text { femoral bypass }\end{array}$ & $\begin{array}{l}\text { Hypertension, right lower limb } \\
\text { pain }\end{array}$ & 5 weeks & C. albicans \\
\hline Wang et a $\left.\right|^{15}$ & $\mathrm{~F}$ & 40 & $\begin{array}{l}\text { Graft nephrectomy with excision } \\
\text { of pseudoaneurysm }\end{array}$ & $\begin{array}{l}\text { Acute abdominal pain with } \\
\text { hypotension }\end{array}$ & 10 days & Aspergillus fumigatus \\
\hline Wang et al ${ }^{15}$ & M & 35 & $\begin{array}{l}\text { Graft nephrectomy with excision } \\
\text { of pseudoaneurysm }\end{array}$ & $\begin{array}{l}\text { Acute abdominal pain with } \\
\text { hypotension }\end{array}$ & 3 weeks & A. fumigatus \\
\hline Wang et a $\left.\right|^{15}$ & M & 29 & $\begin{array}{l}\text { Graft nephrectomy with excision } \\
\text { of pseudoaneurysm }\end{array}$ & Oliguria & 5 weeks & Aspergillus \\
\hline Wang et al ${ }^{15}$ & M & 33 & $\begin{array}{l}\text { Graft nephrectomy with excision } \\
\text { of pseudoaneurysm }\end{array}$ & Asymptomatic & 8 weeks & A. fumigatus \\
\hline Bracale et $\mathrm{al}^{3}$ & $\mathrm{~F}$ & 40 & $\begin{array}{l}\text { Graft nephrectomy, excision of } \\
\text { pseudoaneurysm with femoral- } \\
\text { femoral bypass }\end{array}$ & Fever, local pain, tender mass & II weeks & C. albicans \\
\hline Orlando et al ${ }^{19}$ & M & 57 & $\begin{array}{l}\text { Graft nephrectomy with donor } \\
\text { aortic cuff patch repair }\end{array}$ & $\begin{array}{l}\text { Retroperitoneal hemorrhage } \\
\text { with shock }\end{array}$ & 8 days & $\begin{array}{l}\text { Pseudomonas } \\
\text { aeruginosa }\end{array}$ \\
\hline Bracale et $\mathrm{al}^{9}$ & M & 47 & $\begin{array}{l}\text { Graft nephrectomy, excision } \\
\text { of pseudoaneurysm with silver } \\
\text { polyester interposition graft }\end{array}$ & Fever, pulsatile mass & 10 months & C. albicans \\
\hline Minz et $\mathrm{al}^{8}$ & M & 36 & $\begin{array}{l}\text { Graft nephrectomy, excision } \\
\text { of aneurysm with internal iliac } \\
\text { artery graft reconstruction }\end{array}$ & $\begin{array}{l}\text { Fever, acute right lower limb } \\
\text { ischemia }\end{array}$ & 3 months & Aspergillus flavus \\
\hline Minz et $\mathrm{al}^{8}$ & M & 36 & $\begin{array}{l}\text { Graft nephrectomy, excision } \\
\text { of aneurysm with internal iliac } \\
\text { artery graft reconstruction }\end{array}$ & Asymptomatic & 4 months & A. flavus \\
\hline $\begin{array}{l}\text { Ram Reddy } \\
\text { et al }{ }^{16}\end{array}$ & M & 42 & $\begin{array}{l}\text { Graft nephrectomy with vein } \\
\text { graft reconstruction }\end{array}$ & Fever, dysuria, hematuria & 3 weeks & A. flavus \\
\hline $\begin{array}{l}\text { Ram Reddy } \\
\text { et } \text { al }^{16}\end{array}$ & M & 46 & $\begin{array}{l}\text { Graft nephrectomy with vein } \\
\text { graft reconstruction }\end{array}$ & Fever, oliguria & 5 months & A. flavus \\
\hline $\begin{array}{l}\text { Leonardou } \\
\text { et } \mathrm{al}^{4}\end{array}$ & M & 42 & $\begin{array}{l}\text { Balloon expandable covered } \\
\text { stent, then aneurysmectomy with } \\
\text { femoral-femoral bypass }\end{array}$ & $\begin{array}{l}\text { Fever, right lower quadrant } \\
\text { pain, acute right lower limb } \\
\text { ischemia }\end{array}$ & 3 months & Mucorales \\
\hline $\begin{array}{l}\text { Leonardou } \\
\text { et } \mathrm{al}^{4}\end{array}$ & M & 67 & $\begin{array}{l}\text { Covered stent insertion, then } \\
\text { graft nephrectomy }\end{array}$ & Fever, left iliac fossa pain & N/A & $P$. aeruginosa \\
\hline $\begin{array}{l}\text { Leonardou } \\
\text { et } \mathrm{al}^{4}\end{array}$ & $\mathrm{~F}$ & 57 & $\begin{array}{l}\text { Covered stent insertion, then } \\
\text { graft nephrectomy }\end{array}$ & Fever, left iliac fossa pain & N/A & P. aeruginosa \\
\hline $\begin{array}{l}\text { Leonardou } \\
\text { et } \mathrm{al}^{4}\end{array}$ & M & 57 & Balloon expandable covered stent & Fever, right lower quadrant pain & 3 months & Klebsiella pneumoniae \\
\hline $\begin{array}{l}\text { Leonardou } \\
\text { et } \mathrm{al}^{4}\end{array}$ & $\mathrm{~F}$ & 21 & $\begin{array}{l}\text { Coil embolization of } \\
\text { pseudoaneurysm and covered } \\
\text { stent, then graft nephrectomy }\end{array}$ & Fever, iliac fossa pain & 15 months & Candida \\
\hline $\begin{array}{l}\text { Kountidou } \\
\text { et } \mathrm{al}^{6}\end{array}$ & M & 47 & $\begin{array}{l}\text { Repair of pseudoaneurysm with } \\
\text { vein graft reconstruction }\end{array}$ & Asymptomatic & 3 months & C. albicans \\
\hline
\end{tabular}


Table I (Continued)

\begin{tabular}{|c|c|c|c|c|c|c|}
\hline Study & Sex & $\begin{array}{l}\text { Age, } \\
\text { years }\end{array}$ & Treatment modality & Initial clinical presentation & $\begin{array}{l}\text { Symptom onset } \\
\text { posttransplant }\end{array}$ & Culture results \\
\hline Chandak et al ${ }^{18}$ & $M$ & 40 & $\begin{array}{l}\text { Graft nephrectomy with vein } \\
\text { graft reconstruction }\end{array}$ & Fever, skin rash & 6 months & No growth \\
\hline Patrono et $\mathrm{al}^{17}$ & $M$ & 31 & $\begin{array}{l}\text { Graft nephrectomy with vein } \\
\text { graft reconstruction }\end{array}$ & $\begin{array}{l}\text { Right iliac fossa pain with } \\
\text { hemorrhagic shock }\end{array}$ & 12 days & C. albicans \\
\hline Patrono et al ${ }^{17}$ & $M$ & 36 & $\begin{array}{l}\text { Excision of pseudoaneurysm with } \\
\text { prosthetic graft reconstruction }\end{array}$ & Asymptomatic & 24 days & C. albicans \\
\hline Patrono et al $^{17}$ & $M$ & II & Graft nephrectomy & Left iliac fossa pain & N/A & P. aeruginosa \\
\hline
\end{tabular}

Abbreviations: F, female; $M$, male; N/A, not applicable.

Fujikata et al had demonstrated a successful trial of conservative treatment with antibiotics alone. ${ }^{5}$ Surgical plan should, therefore, be decided on an individual basis depending on the size of the pseudoaneurysm and on the microorganisms involved. Lifelong antibiotics were indicated, especially in those with immunosuppression, and regular surveillance follow-up is also required to rule out recurrence even after initial successful open repair. ${ }^{12}$

While most case reports in the literature demonstrated fungal infection in infectious anastomotic pseudoaneurysms of the renal allograft artery, we have successfully treated one caused by the multidrug-resistant $P$. aeruginos , unfortunately with sacrifice of the renal graft. Early detection of infectious aneurysm remains a challenge for many, as most are fungal infections and may be indolent for months. Timely use of radiologic investigations and blood cultures would be helpful, and strict infection control during transplant operation and aseptic handling of the graft or preservation fluid are probably of utmost importance in preventing this potentially lethal infective complication.

\section{Acknowledgment}

This paper was presented in abstract form as "Mycotic anastomotic pseudoaneurysm complicating renal allograft: Case report and review of literature. MT Chung, YC Chan, Y Law, SW Cheng" in RCSEd/CSHK Conjoint Scientific Congress September 2016 in Hong Kong.

\section{Disclosure}

The authors report no conflicts of interest in this work.

\section{References}

1. Aktas S, Boyvat F, Sevmis S, Moray G, Karakayali H, Haberal M. Analysis of vascular complications after renal transplantation. TransplantProc. 2011;43(2):557-561.

2. Mulderije ED, Berden JH, Buskens FG, Raaijmakers PA, Rosenbusch G. False and true aneurysms of the renal artery after kidney transplantation. A report of two cases. BrJRadiol. 1985;58(693):896-899.
3. Bracale UM, Carbone F, del Guercio L, et al. External iliac artery pseudoaneurysm complicating renal transplantation. InteractCardiovascThoracSurg. 2009;8(6):654-660.

4. Leonardou P, Gioldasi S, Zavos G, Pappas P. Mycotic pseudoaneurysms complicating renal transplantation: a case series and review of literature. J Med Case Rep. 2012;6:59.

5. Fujikata S, Tanji N, Iseda T, Ohoka H, Yokoyama M. Mycotic aneurysm of the renal transplant artery. Int J Urol. 2006;13(6):820-823.

6. Kountidou CS, Stier K, Niehues SM, et al. Successful repair of posttransplant mycotic aneurysm of iliac artery with renal graft preservation: a case report. Urology. 2012;80(5):1151-1153.

7. Marik PE. Fungal infections in solid organ transplantation. Expert OpinPharmacother. 2006;7(3):297-305.

8. Minz M, Sharma A, Kumar S, Singh S, Shivaprakash MR, Bag S. Use of autogenous internal iliac artery for bridging the external iliac artery after excision of Aspergillus mycotic aneurysm in renal transplant recipients. JVasc surg. 2011;53(3):802-804.

9. Bracale UM, Santangelo M, Carbone F, et al. Anastomotic pseudoaneurysm complicating renal transplantation: treatment options. EurJVascEndovascSurg.2010;39(5):565-568.

10. Osmán I, Barrero R, León E, Medina R, Torrubia F. Mycotic pseudoaneurysm following a kidney transplant: a case report and review of the literature. PediatrTransplant. 2009;13(5):615-619.

11. Smeds MR, Ofstein R, Peterson GJ, Peterson BG, Jacobs DL. Endovascular repair of a para-anastomotic pseudoaneurysm after renal autotransplantation: an alternative to open reconstruction. AnnVascSurg. 2013;27(1):110.

12. Potti A, Danielson B, Sen K. "True" mycotic aneurysm of a renal artery allograft. AmJKidney Dis. 1998;31(1):E3.

13. Garrido J, Labrador PJ, Lerma L, et al. [Vascular Aspergillus infection in two recipients of kidneys from the same donor]. Nefrologia. 2004; (24 Suppl 3):30-34. Spanish.

14. Laouad I, Buchler M, Noel C, et al. Renal artery aneurysm secondary to Candida albicans in four kidney allograft recipients. TransplantProc. 2005;37(6):2834-2836.

15. Wang R, Wu J, Wang Y, Huang H, He Q, Chen J. Aspergillus infection limited to the anastomosed artery following renal transplantation: a report of 4 cases. TransplInfectDis. 2009;11(4):363-366.

16. Ram Reddy C, Ram R, Swarnalatha G, et al. "True" mycotic aneurysm of the anastomotic site of the renal allograft artery. ExpClinTransplant. 2012;10(4):398-402.

17. Patrono D, Verhelst R, Buemi A, Darius T, Godefroid N, Mourad M. Presentation and management of mycotic pseudoaneurysm after kidney transplantation. Transpl Infect Dis. 2015;17(1):129-136.

18. Chandak P, Kessaris N, Uwechue RU, et al. Successful excision of a suspected mycotic transplant renal artery patch aneurysm with renal allograft autotransplantation. Transplantation. 2014;97(3):e25-e26.

19. Orlando G, Di Cocco P, Gravante G, D’Angelo M, Famulari A, Pisani F. Fatal hemorrhage in two renal graft recipients with multi-drug resistant Pseudomonas aeruginosa infection. TransplInfectDis. 2009;11(5): $442-447$. 
The International Journal of Nephrology and Renovascular Disease is an international, peer-reviewed open access journal focusing on the pathophysiology of the kidney and vascular supply. Epidemiology, screening, diagnosis, and treatment interventions are covered as well as basic science, biochemical and immunological studies. The manuscript management system is completely online and includes a very quick and fair peer-review system, which is all easy to use. Visit http://www. dovepress.com/testimonials.php to read real quotes from published authors.

Submit your manuscript here: https://www.dovepress.com/international-journal-of-nephrology-and-renovascular-disease-journal 